\title{
It takes two to Tango: the difficult Japan-South Korea relations as clash of realities
}

\author{
Taku Tamaki \\ Politics and International Studies (POLIS), School of Social Sciences, Loughborough University, Loughborough LE11 3TU, UK \\ Corresponding author. Email: T.Tamaki@lboro.ac.uk
}

(Received 5 September 2018; revised 7 February 2019; accepted 4 August 2019; first published online 7 October 2019)

\begin{abstract}
Why do Japan-South Korea relations remain tense despite repeated efforts to overcome the past? Elite narratives in Japan and South Korea reify the bilateral relationship as a difficult problem. For the Japanese policy elites, the difficulty is due to South Korean unwillingness to embrace a future-oriented relationship; whereas for the South Korean policy elites, the source of the problem is the unwillingness of the Japanese to sincerely address past wrong-doing. The result is a self-fulfilling prophecy of an intractable mutual misapprehension, suggesting that the difficult relationship is here to stay. I analyse pronouncements by both the Japanese and South Korean policy elites appearing in official documents and media reports for clues into the manner in which the bilateral relationship is reified into a difficulty purportedly due to the recalcitrance of the neighbour. The narratives consistently show that both the Japanese and South Korean policy elites consider the onus of improvement lies with the troublesome/insincere neighbour. In short, the bilateral relationship is a clash of realities, with the logical conclusion being that the difficult relationship will persist for the foreseeable future.
\end{abstract}

Key words: Japan; reification; South Korea

Difficulty underpins the bilateral relationship between Japan and South Korea. The difficulty is normally considered a given, being treated as a starting point for discussions. However, if the difficulty is so pervasive, then we need an account exploring the underlying conditions that perpetuate difficulty. From the Japanese policy elites' perspective, the recurring demands for apology are understood as South Koreans' failure to embrace future-oriented relationship. The perception among the South Korean policy elites is one of insincere Japanese insisting that Tokyo is now fully absolved of its wartime record, disparaging South Korean concerns. As Prime Minister Abe Shinzō assumed office for the second time in December 2012, there were initial hopes for improvement, with both governments agreeing in December 2015 to 'finally and irreversibly' resolve the issue of Comfort Women who were forced into sexual slavery by the Japanese during the War. Yet, the appearance in Busan of a new statue memorializing the Comfort Women in December 2016 - produced by South Korean activists calling for reparations from Japan, and first erected in Seoul in 2011 - plunged the relationship further. The pledge to revisit the December 2015 agreement (hereafter, the Agreement) on Comfort Women by the South Korean President, Moon Jae-in, who assumed office in May 2017, further prompted the Japanese government to accuse the South Korean government of reneging on an international agreement.

Why do Japan-South Korea relations remain difficult despite several efforts to overcome the past? While the Japanese government has been trying to pursue 'future-oriented relationship' (mirai-shikō kankei) since the 1980s, the reality for Japanese elites is one of troublesome South Koreans unwilling to embrace the future-oriented relationship. From the viewpoint of South Korean elites, it is the 
insincere Japanese relentlessly provoking South Korean public opinion, leaving little choice but for the South Korean government to criticize Tokyo, which in turn angers Japanese elites. Insofar as Japanese and South Korean policy circles consider that the onus of improvement lies with the neighbour, the difficult relationship becomes a self-fulfilling prophecy. The 'stickiness' of reality suggests that, unless Tokyo and Seoul concede that they themselves are actively involved in the reproduction of difficult relationship, the difficulty is reconfirmed and the clash of realities - where irreconcilable differences in perceived realities fuel mutual antagonisms - across the Tsushima strait will persist into the foreseeable future.

I focus on the elite narratives since the summer of 2012 since the period captures the clash of realities well. By elites, I refer to policy makers, legislators and bureaucrats who are involved in policy making, as well as those who are in a position to influence thinking on bilateral relations. When the actors are accused of being troublesome or insincere, difficulty as a label takes on a life of its own and the conflict becomes ingrained. Difficulty as a reification is so potent that the future of bilateral relations looks bleak since the image of troublesome/insincere neighbour is bound to become a self-fulfilling prophecy. Theoretically, I utilize the concept of reification. As I show below, using reification as a concept helps us to appreciate how even a figment of one's imagination comes to be seen as incontrovertibly real. Reification helps us to appreciate how actors' interactions with one another reproduce and reinforce mutual Othering. Once neighbours believe that they are consigned to a difficult relationship, difficulty as an idea governs their relationship.

This paper is divided into four sections. The first section argues that the existing literature underplays the clash of realities experienced by both the Japanese and South Korean policy elites, focusing, instead, on the implications of a difficult relationship. The second section discusses the Japanese elite narratives from 2012 to show how South Korea is perceived as an obdurate troublesome reality, refusing to embrace the future-oriented relationship. The third section explores the South Korean reality of Japan as an insincere neighbour whose response to the past remains an impediment to a better relationship. These two sections provide a detailed empirical account of the clash of realities as experienced by policy elites. Finally, in the fourth section, I argue that the empirical evidence suggests that the mutual images, as a product of clash of realities, boomerang back on to the actors as an irrefutable reality governing the relationship, reproducing a downward spiral of mutual misgivings.

\section{The enigma of Japan-South Korea relations}

The existing literature on bilateral relations considers the difficult relationship as a given, highlighting the seeming intractability of mutual animosities, when the very characteristic of this relationship remains a social construct. For Lee (2016b), 'mutual security anxiety' defines the difficult JapanSouth Korea relations while Wiegand (2015: 355) argues that South Korea considers the dispute over Dokdo/Takeshima to be 'inseparable' from the legacies of Japanese colonialism and unless Japan admits to war guilt, reconciliation remains elusive. One explanation for the difficulty focuses on domestic politics. Kagotani et al. (2014: 53) argue that 'economic distress drives South Korea's leaders to direct public attention towards the Japan-South Korea disputes'. Wiegand (2015: 357) suggests that ' $[w]$ hen domestically vulnerable, Korean leaders have had to balance their policies related to Dokdo with their foreign policies related to Japan, particularly security issues'. Rozman and Lee (2006: 764-767) observe that, despite Japan and South Korea being US allies and sharing regional security concerns, leadership in Japan and South Korea cater to domestic, nationalistic, pressures. Lind (2010) argues that competing narratives over the past can provoke backlash over statements of contrition that worsen relations.

Another explanation focuses on ideational factors. As Kim (1995: 76) notes, the bilateral relationship is a clash of nationalisms, and Lee (2013: 94) suggests that ideational elements are at the root of a difficult relationship, and mutual misgivings fuel negative dynamics. Sakaki and Nishino (2018: 1) capture the dynamics from the Japanese perspective well, arguing that 'the negative trajectory of political relations since 2011 has reinforced Japanese perceptions of South Korea as not only difficult but 
an unreliable partner in regional security affairs'. As a result, the Japanese leaders are 'bewildered' at the recurrence of history issue to 'cloud [South Korean] strategic thinking' (Sakaki and Nishino, 2018: 8), adding that, " $[\mathrm{t}]$ he Japanese policy-making community and the wider public perceive South Korea as a nation preoccupied with the past and incapable of shaking off its hatred of Japan' (Sakaki and Nishino, 2018: 13). For Sakaki and Nishino (2018: 18), Tokyo is left in a 'predicament' such that the Japanese leaders 'feel that their capability to bring about a reset in relations with Seoul is limited'.

The entrenched nature of bilateral relations requires an explanation that addresses why such difficulty persists. The sense of resignation in Tokyo and Seoul indicates that the difficulty is understood as an obdurate reality, requiring an account of how mutual ideas reinforce the notion of an inescapable, self-perpetuating, difficulty.

\subsection{Reification as an irrefutable reality}

It seems as if Japanese and South Korean policy elites inhabit competing realities clashing with one another, turning difficulty into a self-perpetuating reality. Here, reification as a concept becomes useful. Reification is defined as mistaking an abstract notion for a thing, but reification can also be used to explore actors' perceived realities. As Bieler and Morton (2008: 115) note, the social world attains a sense of 'as if they are real' in the process of 'objectivation or reification'. Archer (1995: 196) suggests that 'all structural influences are mediated to people by shaping their situation in which they find themselves', adding that '[c]ulture is man-made, but escapes its makers to act back upon them' (Archer, 1996: 107). Elder-Vass (2012: 248) argues that 'reality is not external or 'out there'; but both inside and outside us', suggesting that '[s]ocial structures are indeed things, but they are dynamic things whose powers depend on the activities of the people' (Elder-Vass, 2010: 196). In other words, '[t] here is therefore a continuous cycle of interaction between social structure and individual action' in a way that actors respond to the social context they themselves helped reproduce as an obdurate reality - even if they are unaware of their own authorship in the reproduction of the social reality (Elder-Vass, 2007: 26).

According to Honneth (2005: 96), 'reification signifies nothing but the fact that a "relationship between people had taken on the character of a thing"', adding that it is almost as a 'second nature' for actors to reify a particular social context that presents itself as an obdurate social reality (Honneth, 2005: 97-98). Honneth (2005: 99) points out that reification is an actor's own 'creation'; but 'subjects also begin to perceive their surroundings as mere thing-like givens'. Moreover, Honneth (2005: 125) suggests that the perceived reality of a social context is predicated on forgetting one's own involvement in its reproduction, prompting an actor to feel that the reified reality is irrefutable. The complexities of social reality and the limitations in the actor's capacity to process them mean that reification acts as a coping mechanism. Pitkin (1987: 279) argues that '[r] eification in this sense can be good or bad; it is a matter of getting reality right', and that we can feel as if we are 'trapped' in our own reified social context (Pitkin, 1987: 286). As Silva (2013: 80) notes, reification is a 'universal human tendency to apprehend abstraction as things'.

The Japan-South Korea case reveals how reified images poison the bilateral relationship. To appreciate the persistence of purported troublesome/insincere neighbour, we need to consider what I call the 'stickiness' of reality - the difficulty in questioning one's own reality, thereby reproducing that reality. The precision of reification is less important, as it is the obduracy of perceived reality - even if they are figments of actors' imaginations.

Consider actors, Alter and Ego. For Alter, a friendly interaction creates positive images of Ego, labelling the relationship as amicable; while an angry encounter with Ego prompts Alter to define the relationship as hostility, even if Alter intended friendship. If Alter defines the relationship as hostile, that label takes on a life of its own, prompting Alter to consider Ego as troublesome and the relationship as difficult, thereby confirming the hostile relationship. Here, Alter's assumption is that Alter's friendly intentions are clear from the outset, putting the onus on Ego to improve the relationship while disregarding the role that Alter might have played in Ego's behaviour. 
A similar dynamic is at play in Ego's images of Alter: we need to determine what might have prompted Ego to respond to Alter's purportedly 'friendly' overture with a 'hostile' response. It is possible that Alter and Ego have been interacting for some time, and that Ego's earlier interaction with Alter was perceived negatively. As a result, both Alter and Ego feel that the ball is in the other's court, always expecting the Other to compromise. If no improvement is forthcoming, then both actors become resigned to consider one's amicable overture will be misconstrued, further poisoning the relationship. We now have a reified reality of a hostile relationship: hostility has become the governing reality for Alter and Ego.

The stickiness of reality is a cause for concern. Unless both Alter and Ego realize that the reality can be changed, and are ready to accept what might be construed as a concession, the prospect for reconciliation remains remote since Alter and Ego would feel that they are 'losing face'. If that is the case, hostility is reconfirmed since Alter and Ego believe that the onus of improvement lies with the neighbour and are resigned to live in a perpetually hostile environment. So long as Alter and Ego remain hostile towards one another, enmity will be reinforced, and the reality of a difficult relationship and troublesome/insincere neighbours becomes reified.

Maruyama (1961: 127) captures the essence well. Reification is akin to what he calls the bakemono (the 'monster'). Maruyama (1961: 127-128) notes that human experience revolves around perceptions, and that the emergent ideas about the world tend to assume lives of their own to the extent that illusions become more real than reality. Applying Maruyama's idea of bakemono, the Japanese government's image of recalcitrant South Korea is akin to a bakemono that is troublesome to deal with; and the Japanese government is resigned to expect a constant struggle with the bakemono. The South Korean government sees Japan refusing to sincerely atone for war atrocities becoming a bakemono that is insincere and always in denial. Once these mutual monsters are reified, both governments place the onus of improvement on each other, as bakemono is the one to be blamed for the difficulty.

The reality of a difficult relationship between Japan and South Korea is a product of longer, iterated, interactions. The difficult relationship predates the annexation in 1910, as it can be traced back to the Japanese military expedition to Kanghwa Island in 1875, if not the invasion of Korea by Toyotomi Hideyoshi in 1592. Japan's steady erosion of Korean sovereignty in the early twentieth century and the harsh colonial rule during the annexation provide legitimate grounds for South Korean grievances. ${ }^{1}$ The immediate postwar years also witnessed a series of setbacks, including the infamous Kubota Remark of 1953 in which the Japanese chief negotiator in the normalization talks, Kubota Kanichirō, suggested annexation had positive aspects as well (Tamaki, 2010). There was a sense of rapprochement in the 1980s after Prime Minister Nakasone Yasuhiro chose South Korea for his first official visit coinciding with the steady liberalization in South Korea encouraging positive Japanese images of its neighbour. But the relationship also suffered setbacks in 1982 when Japanese school textbooks watered-down descriptions of Japan's wartime behaviour (Wakamiya, 2006: 206). Yet, a bout of rapprochement followed the cordial visit to Tokyo by President Kim Dae-jung in 1998. The positive outcome of the 1998 summit culminated in Japan and South Korea co-hosting the World Cup in 2002. The rapprochement of the late 1990s and early 2000s looked as if bilateral relations were finally entering a positive trajectory. But Prime Minister Koizumi Junichirō's visits to the controversial Yasukuni Shrine in the early 2000s, as well as the establishment of the Takeshima (Dokdo) Day in Japan in 2005 gave South Koreans the impression that Japan remains keen to justify colonialism (Lee, 2016a: 6). The Korean Constitutional Court ruling in August 2011 criticizing the South Korean government for its inadequate treatment of former Comfort Women hastened the downward spiral, prompting the South Korean government to push Japan for new negotiations on Comfort Women, which Japan eventually agreed. President Lee Myung-bak was under immense domestic pressure to assume a hardline stance on Japan, compelling Lee to visit the disputed Dokdo in August 2012 in protest at the Comfort Women issue (Lee, 2016a: 7), but also to allay domestic criticisms about his approach to the General Security of Military Information Agreement (GSOMIA) with Japan. The uproar over

${ }^{1}$ For detailed discussions on Japan's historical relationship with Korea, see Banno (2013), Duus (1995) and Iriye (1966). 
the Comfort Women Agreement of December 2015 accelerated the downward spiral of mutual invectives in recent years. Reification as a concept plugs the gap in literature allowing us to reframe the bilateral relations as a clash of realities. The post-2012 relationship exemplifies the characteristics of this reified reality.

\section{South Korea as a troublesome neighbour}

Having made the case for reification, we now explore the narratives of Japanese policy elites and their perceived reality involving troublesome South Korea refusing to embrace Tokyo's pursuit of the futureoriented relationship. The relationship already suffered a downturn in August 2011, after the South Korean Constitutional Court ruling urged the South Korean government to resolve the Comfort Women issue with Japan. Tokyo responded by reiterating that all compensation issues were resolved under the 1965 normalization agreement. Furthermore, the signing of GSOMIA in July 2012 had been postponed after the South Korean government withdrew at the last minute. The South Korean Foreign Minister, Kim Sung-hwan, stated that the Japanese government pressuring the New Jersey state government in the USA to remove the Comfort Women memorial made it impossible for the South Korean government to sign GSOMIA given the ensuing anti-Japanese sentiments in South Korea (Sankei shimbun, 2012). Furthermore, President Lee Myung-bak's August 2012 visit to the disputed Takeshima/Dokdo reminded the Japanese government of impediments to future-oriented relationship. In response to Lee's visit, the Chief Cabinet Secretary Fujimura Osamu stated that the visit undermined the 'future-oriented diplomacy' by 'gravely hurting our people's feelings and negatively affecting Japan-South Korea relations' (Kantei, 2012). It was within this context overshadowed by the past that Abe returned to premiership.

Abe assumed office for the second time in December 2012 after an electoral landslide by the Liberal Democratic Party (LDP). Abe sought to pursue the future-oriented relationship, engaging in negotiations over the treatment of former Comfort Women. At a meeting of Japan-South Korea co-operation committee in November 2013, Abe wished that the year 2015 marking the 50th anniversary of the normalization of bilateral relations would enhance reconciliation (Kantei, 2013). Simultaneously though, Abe stated in March 2014 that the Japanese government was intent on reassessing the drafting of 1993 Kōno Remark - admitting official Japanese involvement in sex slavery - while indicating that Tokyo had no intention of revising it (Huffington Post, 2014). The June 2014 findings into the Kono Remark suggested that there was significant input from the South Korean government - though Chief Cabinet Secretary, Suga Yoshihide, reiterated the official position not to revisit the Remark itself (Kantei, 2014). In February 2015, the Japanese government decided to send an official to the annual celebration of Takeshima Day held in Shimane Prefecture commemorating Japan's territorial claims over the Takeshima/Dokdo islands. Responding to South Korean criticism, Foreign Minister Kishida Fumio stated that the commemoration on 22 February is 'not designed to make JapanSouth Korea relations worse' (MOFA, 2015), insinuating that South Korea was over-reacting.

There was some hope for improvement in the 50th anniversary year of normalization, as negotiations were under way to resolve the Comfort Women issue. During the June 2015 commemoration of the Basic Treaty, Abe emphasized that 'cultural exchanges since the signing of the treaty are the indispensable legacies of normalization' (Kantei, 2015b). The year 2015 was also significant, marking the first Japan-South Korea summit since 2012. When Abe met South Korean President Park Geun-hye in November, Abe urged South Korea to put the past behind and pursue 'future-oriented relations to make sure that our future generations are not burdened by the Comfort Women issue' (Kantei, 2015a).

To Abe's credit, his administration engaged with the Comfort Women problem, culminating in the December 2015 bilateral Agreement as a 'final and irreversible' closure. The South Korean government agreed to address the issue of the statue in front of the Japanese embassy in Seoul which had riled the Japanese government since December 2011 - language the Japanese government interpreted as removal. The significance of this Agreement cannot be underestimated as Abe risked alienating his 
nationalist base. Indeed, conservative commentators decried the Agreement, with Nishioka (2016) claiming that the Agreement failed to expunge 'the root cause [kokan]' of lies about Comfort Women, 'effectively spreading the lie that' Japan violated human rights. A Japanese conservative activist group, Gambare Nippon, condemned the Agreement as 'worse than Kōno Remark', with a former member of the Upper House, Nakayama Kyōko, arguing that 'it effectively tells the world that Japan is a cruel beast [kemono no yōni zankoku]' (Sankei shimbun, 2016). Emphasizing that the ball is now in South Korea's court, Abe reminded Park in September 2016 that, since the Japanese government had pledged 10 billion yen to compensate former Comfort Women, 'it was now South Korea's turn' (Nihon keizai shimbun, 2016b: 4).

Park's resignation in November 2016 following corruption allegations worried the Japanese government concerned with South Korean commitment to the Agreement (Mutō, 2017: 288-289). The Secretary General of LDP, Nikai Toshihiro, noted his 'pity' adding that the Agreement is a promise between the two countries. I remain optimistic' (Nihon keizai shimbun, 2016a: 4). The chairman of the LDP Policy Research Council, Motegi Toshimitsu, stated that '[I] want to make sure that Japan-South Korea relations we have nurtured are not adversely affected', while the Secretary General of the JapanSouth Korea Parliamentary League, Kawamura Tateo, urged South Korea to 'make sure the Agreement is implemented' (Nihon keizai shimbun, 2016a: 4). It was within this context that the issue of Comfort Women resurfaced in late 2016 reminding the Japanese government of South Korea's continued refusal to embrace the future-oriented relationship.

As if to confirm Japanese belief that South Koreans remain obsessed with the past, another statue of Comfort Woman was set up by a civic group in South Korea in December 2016, this time across the road from the Japanese consulate in Busan. For Japan, it was tantamount to a violation of the Agreement. The Japanese government recalled its ambassador to South Korea in protest, with the Japanese Ministry of Foreign Affairs (MOFA) Vice Minister, Sugiyama Shinsuke, remonstrating that this 'violates last year's Japan-South Korea Agreement. It is extremely regrettable' (Yamada, 2016: 2). Suga warned that the new statue 'impacts negatively on Japan-South Korea relations', calling for the 'Agreement ... to be fully implemented' (Nihon keizai shimbun, 2017c: 1). The president of Japan-South Korea parliamentary league, Nukaga Fukushirō, revealed his irritation at the perceived South Korean recalcitrance, stating in January 2017 that 'I want to make sure the South Korean government works very hard [ase wo kaite morau]' to improve the situation (Asahi shimbun, 2017j). In a similar vein, Nikai stated in January 2017 that South Korea remains a troublesome country [mendō na kuni da] to deal with (Asahi shimbun, 2017i). In January 2017, Nukaga argued that 'the public wants a new Japan-South Korea relations and politics must not let them down [seiji ga uragiruna]' (Asahi shimbun, 2017h).

Japanese officials engaged in a media offensive to emphasize the difficult reality of South Korea frustrating the future-oriented relationship. Writing in The Japan Times in January 2017, MOFA spokesperson, Kawamura Yasuhisa, argued that it is highly regrettable that a South Korean activist group installed a statue at the end of last year', adding that Japan wants 'to advance relations with South Korea in a future-oriented manner' (MOFA, 2017b). Similarly, Parliamentary Vice-Minister for Foreign Affairs, Odawara Kiyoshi, wrote in The Wall Street Journal in January 2017 stating that 'we expected' the South Korean government to pursue future-oriented relationship so that Japan and South Korea could celebrate the first anniversary of the Agreement, but it is a bitter disappointment that we had to protest' (MOFA, 2017a).

The election of Moon Jae-in as the new president of South Korea in May 2017 reinforced Japan's reality of a difficult relationship due to South Koreans frustrating Japanese attempts at reconciliation. The Moon administration's decision to reassess the Agreement reinforced Japanese belief that the future-oriented relationship with South Korea remained elusive. In a May 2017 press conference, Suga stated that, 'as a country sharing strategic interests, ... we would like to forge future-oriented new era' (Asahi shimbun, 2017g), a sentiment reiterated by Abe in his phone conversation with Moon a few days later (Asahi shimbun, 2017f). Yet, when Nikai visited South Korea in June 2017, he told his audience that 'there are a handful of malcontents [waru-dakumi wo suru rench $\bar{u}$ ] intent 
on derailing Japan-South Korea relations. I want you to exterminate them [bokumetsu suru]' (Yamagishi, 2017). By August 2017, there was a hint of rapprochement. Abe told Moon during the G20 Summit in Hamburg that, while difficulties remain, it is in our mutual interest to manage the bilateral relationship' (Asahi shimbun, 2017e). Moon responded by reassuring Abe that he intends to separate the history issue from security agenda.

But the Japanese government was further frustrated at the perceived South Korean obsession with the past in August 2017 when South Korean activists placed a statue of Comfort Woman inside a bus in Seoul. Suga expressed his irritation, stating that 'it is extremely regrettable .... I don't even feel like saying anything [hatsugen suru ki nimo naranai]' (Asahi shimbun, 2017d). Suga added that, 'it potentially frustrates [mizu wo sasu] mutual efforts a pursuing the future-oriented relationship' (Asashi shimbun, 2017c). Moreover, when Moon suggested on 17 August 2017 that former forced labourers are entitled to compensation, Tokyo interpreted this as a confirmation of South Korean intransigence. Nukaga stated on 22 August that he remonstrated to Moon that 'what is needed is an environment for Japan-South Korea relations to move forward [maeni mukatte susumu]' (Asahi shimbun, 2017b). The new foreign minister, Kōno Tarō, reiterated Japanese exasperation when he stated that 'the Comfort Women issue has been resolved, and I want the South Korean government to implement [the Agreement]'; and as for the issue of forced labourers, this issue 'has been resolved, and there is nothing for us to discuss' (Asahi shimbun, 2017b).

Yet, when the American President Donald Trump visited South Korea during his tour of East Asia in November 2017, the South Korean government welcomed Trump with a banquet in which a shrimp from the disputed Dokdo/Takeshima was served. Furthermore, a former Comfort Woman was invited to meet Trump, annoying the Japanese government at witnessing South Korea internationally discrediting Japan. The Japanese government interpreted South Korean action as a provocation, deploring South Korea's 'inappropriate' (tekisetsu de nai) behaviour in inviting a former Comfort Woman, and the serving of 'Dokdo shrimp' to be 'unacceptable' (ukeire rarenai) (Nihon keizai shimbun, 2017b: 9). Suga doubted 'South Korean sincerity' (dō kato omou), insisting that South Korea 'should refrain from actions negatively affecting Japan-South Korea relations' (Nihon keizai shimbun, 2017b: 9). Nukaga condemned South Korean behaviour, telling the members of his faction that it is highly regrettable' and that he wished South Koreans would 'conduct a diplomacy of grown-ups [otona no gaikō]' (Asahi shimbun, 2017a). Nikai (2017: 126) summed up the anger well, stating in July 2017 that the South Korean behaviour is 'humiliating' (konna kutsujoku-teki na koto), and that the Japanese government should tell South Koreans that 'Japan is dissatisfied [ fuman]'.

The South Korean announcement in December 2017 that the Agreement required revisiting due to serious doubts over the negotiating process reinforced the Japanese image of troublesome South Korea uninterested in embracing the future-oriented relationship with Japan. Abe emphasized his belief that the history issue has been resolved, stressing that 'the Agreement remains solid - it will not move even one millimeter' (Nihon keizai shimbun, 2017a: 3). The relationship deteriorated to the extent that, for a period, Abe considered personally boycotting the 2018 Pyeongchang Olympics (Nihon keizai shimbun, 2018: 4), though he later changed his mind. Abe later stated in January 2018 that he had decided to go to the Olympics and meet Moon, but stressed that the Japanese government '[c]annot accept unilateral demands from South Korea' (Takita and Abiru, 2018). Abe reiterated his frustration in an interview with The Japan Times in February 2018, claiming that '[m]any people in Japan find [South Korean behaviour] frustrating' (Mizuno and Osaki, 2018).

The South Korean Supreme Court ruling in October and November 2018 allowing former forced labourers to seek damages from Japanese companies confirmed the Japanese government's conviction that South Korea remains obsessed with the past. Kōno protested that the ruling was 'reckless' (bōkyo) and a 'challenge [chōsen] to international rule of law' repudiating the 1965 normalization (Kiyomiya, 2018). Kōno protested in October 2018 that 'the legal principle governing the bilateral relationship has been damaged', accusing the South Korean government of reopening historical wounds (Kiyomiya and Takeda, 2018). For a former Japanese ambassador to South Korea, Mutō (2018: 175), South Korea 'crossed a line', insinuating that Moon plays dirty: 'while Moon talks about "future-oriented 
relationship", he ends up frustrating [ashi wo hipparu] Japan-South Korea relationship' (Mutō, 2018: 178).

In response to Moon's January 2019 speech reproaching Japan for playing politics with the forced labour issue, Suga accused South Korea of fomenting trouble, stating that, 'President Moon's remarks appear to be an attempt to shift South Korea's own responsibilities onto Japan and are extremely dismaying' (Cho, 2019). During the February 2019 Takeshima Day, Shintō Yoshitaka of LDP claimed that 'we have to assume that [South Korea] has given up on maintaining good relations with Japan' (Kinohara and Makino, 2019). The February 2019 statement by South Korean speaker of the National Assembly, Moon Hee-sang, urging the Japanese emperor to apologize to Comfort Women elicited further resentment, with Abe addressing the Diet that 'I am sure many Japanese have experienced anger' at South Korean fixation with the past, with Nukaga telling the South Korean prime minister, 'this is an unforgivable remark' (Onchi, 2019). Hence, from the Japanese perspective, despite Tokyo's constant efforts at pursuing the future-oriented relationship, the reality is one of troublesome South Koreans obsessed with history.

\section{The reality of an insincere Japan}

If the Japanese reality entails a troublesome South Korea refusing to embrace future-oriented relationship, then the reality for South Korean policy elites is insincere Japan ignoring South Korean feelings. Ever since the South Korean Constitutional Court urged the South Korean government in August 2011 to provide better treatment of former Comfort Women, both the South Korean and Japanese governments have been exploring ways to resolve the issue. During the December 2011 summit, President Lee Myung-bak told the Japanese Prime Minister Noda Yoshihiko that, ' $t$ the Comfort Women issue is one that can be resolved immediately if the Japanese government changes its understanding of it' (Ahn, 2011). Noda responded that Comfort Women statues erected by South Korean activists were regrettable. In March 2012, Lee stated that, 'we require the true courage and wisdom to not ignore the two countries' true history if [South Korea and Japan] are to remain as true partners' (Ahn, 2012a). Lee intended his August 2012 visit to Dokdo as a punishment for insincere Japan (Ahn, 2012b). A Blue House spokesperson, Park Jung-ha, explained that President Lee 'felt the need to show [Japan] with action because they're being so reluctant due to domestic political concerns' (Ahn, 2012b).

Park Geun-hye, who succeeded Lee, stated during the anniversary of the March 1st Movement in 2013 that 'the historical perspective of aggressor and victim cannot be changed', adding that, '[i]t is incumbent upon Japan to have a correct understanding of history and take on an attitude of responsibility' (Park, 2013). The Japanese government's announcement in March 2014 that it is intent on reviewing the circumstances leading up to the Kōno Remark of 1993 reinforced the image of insincere Japanese consistently ignoring South Korean feeling. The South Korean Foreign Ministry stated that,

The South Korean government cannot accept the Japanese government raising questions about the compulsory nature of the recruitment, transportation, and management of the Comfort Women.... We strongly urge the Japanese government not to rashly force those women to once again endure such unbearable pain and anguish (Gil and Kim, 2014).

After Abe announced in March 2014 that the Japanese government will not revise the Kōno Remark, Park stated that she 'hoped that this can lead to ... more stable relations for South Korea and Japan and for Northeast Asia' (Seok, 2014). But the June 2014 Japanese report into the Kōno Remark suggesting that there was a significant South Korean input confirmed Seoul's image of an insincere Japan neglecting South Korean sense of injustice. The First Vice Minister for Foreign Affairs, Cho Tae-yong, admonished the Japanese government for its insincerity, stating that 'the more [the Japanese government] tries to chip away at the Kono Statement, the more its credibility and international reputation will suffer' (Park, 2015). 
South Korean misgivings about an insincere Japan persisted. On the eve of the June 2015 commemoration marking the 50th anniversary of normalization, Foreign Minister Yun Byung-se reiterated that, 'any summit that does take place would have to do so with something of an understanding between the two leaders on the [Comfort Women] issue' (Gil et al., 2015). South Korea and Japan negotiated the Comfort Women problem through 2015, and the 50th anniversary of normalization was an incentive to resolve the differences. The bilateral summit finally took place in November 2015; but the Blue House Senior Secretary, Kim Kyou-hyun, warned that 'the comfort women issue is becoming a stumbling block for improving bilateral relations', insinuating that Japanese insincerity remains an impediment to a better relationship (Choi et al., 2015). After the summit, Park stressed the need for sincerity from Japan, demanding that Tokyo 'make decision to attend to the wounds of the past and heal them' (Choi, 2015).

Eventually in December 2015, both the South Korean and Japanese governments agreed to 'finally and irreversibly' settle the Comfort Women issue. In response, Park hoped that 'the bilateral relations would start anew through implementing the agreement conscientiously' (KH Digital 2, 2015). Yet, the issue persisted as if to confirm Japan's stubborn insincerity when the Japanese government insisted on the removal of the Comfort Woman statue in front of the Japanese embassy in Seoul. But, as the statue was erected by a non-governmental organization (NGO), the Foreign Ministry spokesperson, Cho June-hyuk stated that, '[1] et me make this clear: the statue of the young girl was set up by private citizens, and there is nothing that the government can do about this' (Lee and Gil, 2016). The Japanese government's denial in the United Nations of wartime forced sex labour further confirmed the image of unrepentant Japan, fuelling the discontent that the Agreement was premature. Minjoo Party issued a statement, suggesting that 'we cannot withhold our rage against the Japanese government's brazen act that completely denies and overturns the agreement made just a month earlier' (KH Digital 2, 2016). To highlight the level of domestic opposition to the Agreement, politician, Ahn Cheol-soo, criticized the South Korean government, stating that, ' $[w]$ hile ... Abe and the government is continuing to release ludicrous statements, President Park Geun-hye is not saying anything back.... Whose president is she, turning her back against the people's pain' (KH Digital 2, 2016).

In January 2017, a South Korean Administrative Court ordered the release of documents relating to the Agreement. The Prime Minister and the Acting President Hwang Kyo-ahn stated that, it is advisable to refrain from words or actions that could aggravate the situation' (Jung, 2017a). Foreign Minister, Yun Byung-se addressed the National Assembly Foreign Affairs and Unification Committee meeting, pointing out that the Agreement is an achievement, and releasing the documents would 'diminish South Korea's overseas credibility, and otherwise affect national interest in serious ways' (Lee and Kim, 2017). However, the opposition parties were understandably critical, with Kan Chang-il of Minjoo Party claiming that he 'felt like this was a report from the Japanese Foreign Ministry', and Yoon Young-seok from the Saenuri Party argued that 'I don't think at all that one statement in an agreement means Japan has apologized and reflected' (Lee and Kim, 2017).

Moon Jae-in was elected as the new president in May 2017. In his telephone conversation with Abe soon after assuming office, Moon suggested that 'the reality is that a majority of South Koreans do not emotionally accept the [Agreement]' and that Japanese leaders 'need to show their respect and continuation of the content and spirit of the Kono Statement and the [1998] Joint Communique' (Jung, 2017b). Moon added that 'historical issues must not be allowed to hinder the future-oriented development of bilateral relations' urging the Japanese to apologize honestly (Jung, 2017b). The June 2017 meeting between Moon and Nikai, after Nikai urged the audience to 'exterminate [bokumetsu] malcontents', reaffirmed South Korean mistrust of an insincere Japan intent on ignoring South Korean concerns. Moon reiterated his frustration at a lack of Japanese remorse, stressing that the South Korean public 'frankly cannot accept' the Agreement, and 'more than anything, the comfort women [survivors] themselves do not accept [it]' (Jung and Jung, 2017). Moon told Nikai that, 'the people of Japan need to understand how a South Korean feels about this' (Jung and Jung, 2017).

For South Korea, the future-oriented relationship is contingent upon proper Japanese atonement. Moon told Abe during the July 2017 G20 summit in Hamburg that 'we have to acknowledge the fact 
that the majority of our people find it emotionally difficult to accept [the Agreement]' (Bae, 2017). Moon's August 2017 address commemorating the Liberation Day was imbued with frustration at Japan's purportedly ceaseless insincerity. Moon claimed that the obstacle to an improved relationship is 'the Japanese government's shifting attitude towards dealing with those issues' (Kim, 2017), urging Japan to 'change their position' (Kim, 2017).

For South Korean policy circles, the Agreement highlighted Japan's stubborn refusal to express sincere remorse. The Task Force established by the Moon administration declared the Agreement to be 'severely flawed' (Kim, 2018a). In January 2018, Foreign Minister Kang Kyung-wha stated that the 'biggest flaw [in the Agreement] was the lack of communication with the survivors themselves and the groups working on their behalf (Kim, 2018a). In the same month, Kang reassured the Japanese that the South Korean government is not seeking renegotiation, but stressed that the priority is to '[restore] victims' reputation' (Kim, 2018b). Kang urged Japan to show sincere repentance, stating that she 'hope[d] to see Japan acknowledging the whole truth according to universal international standards and continuing to work to restore the victims' reputations and dignity and heal their emotional wounds' (Kim, 2018b).

Given the deterioration in relations since the Task Force published its findings, Abe threatened to boycott the 2018 Pyeongchang Olympics. However, Abe did attend; and both he and Moon held a meeting. In it, Moon explained to Abe that 'the reason we decided that the comfort women issue has not been resolved is because the former comfort women and the Korean public have not accepted the content of the agreement that was reached by the previous administration' (Kim and Cho, 2018), insinuating that the onus is now on Japan to help realize the future-oriented relationship. Tokyo's refusal to reopen the Agreement and its repeated assertion that legal responsibilities have now been resolved reinforced South Korean frustration at an insincere neighbour.

Moon's address to the ceremony marking the 1919 anti-Japanese demonstration in March 2018 displayed South Korean frustration. Moon urged that, in resolving the issue of sexual slaves, the Japanese government, the perpetrator, must not say it is "over", claiming that the "[i]nhuman violation of human rights during war cannot be covered by saying it is over.... A true resolution only comes from remembering history and learning from that history, especially when it is history of an unfortunate past' (Yonhap, 2018). He told the audience that 'I wish Japan will truly make up with its neighbouring countries that it oppressed and together we walk the path of peaceful co-prosperity.... I simply want Japan to move into the future with us based on sincere reflection and apology' (Yonhap, 2018).

The South Korean resentment over the Agreement led to the dismantling of the Reconciliation and Healing Foundation designed to disburse funds received from the Japanese government. In announcing the decision, Moon stated in August 2018 that '[w] need to bring it to a judicious conclusion' (Kim and Hwang, 2018). The Supreme Court ruling in October and November 2018 affirming the right of former forced labourers to seek compensation elicited anger from the Japanese government condemning the ruling. Japanese reaction to the Supreme Court prompted Prime Minister Lee Nak-yeon to criticize the Japanese for their lack of contrition, issuing his 'deep regret' at the way the Japanese government was reacting, calling it 'neither appropriate nor wise' (Seoung, 2018a). In a similar vein, the Foreign Ministry issued a statement pointing out that the 'South Korean government is very concerned that responsible leaders in the Japanese government have continued to make remarks recently about the Supreme Court's ruling that provoke public sentiment while ignoring the root of the problem', in other words, Japanese insincerity (Seoung, 2018a).

Responding to continued Japanese criticism in November 2018, Kim Byeong-joon of Liberty Korea Party stated that, ' $[w]$ e would like Japan to bear heavily in mind that from the perspectives of members of the South Korean public, we have always been the victims in issues of history' and that 'Japan has always been the party inflicting damage on us' (Lee, 2018). Moon mentioned in November 2018 that ' $\mathrm{t}$ ] he era of colonization represents a painful time for South Korea and Japan alike, but that does not mean we can ignore the truth' (Seoung, 2018b) and in January 2019 he accused the Japanese of exacerbating the dispute, stating that the problem 'is not of South Korea's making. Japanese government should show more humility' (Makino, 2019). Furthermore, the Speaker of National Assembly, 
Moon Hee-sang responded to Japanese criticism of his earlier remark urging the Japanese emperor to apologize in February 2019, asking, '[w] hy ask me to apologize when those who need to apologize have not? The Japanese are behaving like an audacious thief (Suzuki, 2019: 3). For South Korea, the difficulty of bilateral relations stems from the Japanese lack of honest atonement for the past. Japanese government's reluctance to do so confirms the irrefutable difficulty of the relationship.

\section{The clash of realities as a self-fulfilling prophecy}

While the existing literature considers difficulty as a starting point for discussion, employing reification as a theoretical tool points to a self-fulfilling prophecy: that mutual invectives between Japan and South Korea are doomed to repeat. The clash of realities means that both the Japanese and South Korean policy elites can only agree on one thing: that future-oriented relationship is desirable. But since both governments consider the onus of improvement lies with the troublesome/insincere neighbour, any compromise will be interpreted as an unwise concession on both sides within the respective domestic context. The backlash from Japanese conservatives over the Agreement and the South Korean NGO continuing to erect statues are cases in point. It is worth pointing out that the members of the previous Democratic Party of Japan (DPJ) government share similar sentiments to the Abe administration. The former foreign minister, Okada Katsuya, suggested in 2010 that while Japan should apologize, bilateral relations need to be future-oriented (Gaikō, 2010: 16), while the former prime minister, Noda Yoshihiko, told Mainichi shimbun in March 2014 that Park's stance towards Japan resembled 'a schoolgirl telling tales' and that '[w]e should stop using tattletale diplomacy' (Gil, 2014). Noda also blogged in August 2014 that the bilateral relations were already deteriorating during his administration, and instead of Japan turning right-wing, 'the movement to merge nationalism and populism started in South Korea' (J-Cast, 2014).

Similarly, South Korean views of insincere Japan predates the downturn in relations since Abe returned to power. A former Senior Presidential Secretary for Political Affairs in the Park administration, Park Jun-woo, recalls how the rapprochement of 1998 was quickly superseded by friction over the Japanese textbook case, Koizumi's Yasukuni visits, as well as the 2005 Takeshima Day. Park argues that, 'from the South Korean perspective, it was Japan that violated the spirit of the [1998] Communique' (Asahi shimbun, 2018a). Similarly, for Gong Ro-myung, a former South Korean foreign minister in the 1990s, the problem lies with the perceived lack of genuine remorse from the Japanese government. He states that it 'is not a good idea to provoke [South Korean] public sentiments', then condemn South Koreans for the uproar (Makino, 2018). A former foreign minister in the 2000s, Ban Ki-moon, cautioned that 'there is no point in adding fuel to the fire. [The Japanese government] should respect Korean sentiment that [the Koreans] are the victims of war' (Asahi shimbun, 2018b).

Arguably, Abe's nationalism might have exacerbated the conflict. ${ }^{2}$ Abe (2013: 153) wrote in 2006 that Japan needs to be humble (kenkyo) towards its wartime record. Yet, Abe (2013: 154) also wants Japan to be proud of its past and not to be intimidated by Asian criticisms. As for South Korea, Abe (2013: 160-161) wrote that he was optimistic (rakkan-teki), since both Japan and South Korea shared similarities. However, there is a danger that the more this initial enthusiasm is frustrated through the current conflict, the negative images of South Korea will be further exacerbated within the Abe administration - just as the current downward spiral in bilateral relations, particularly after 2016, seems to attest. The logical conclusion is a self-fulfilling prophecy of a difficult relationship. Mutual fingerpointing only reinforces the resignation that bilateral relationship remains difficult.

As the Agreement shows, both the Japanese and South Korean policy elites do actively seek reconciliation, but efforts are frequently frustrated by the words of other Japanese politicians, as well as South Korean non-governmental actors pressuring the South Korean government to stand firmly

\footnotetext{
${ }^{2}$ Abe's political programme of beautiful/new country (utukushii/atarashii kuni) is about revitalizing Japanese economy as a vehicle through which Japan can regain its international prestige. Externally, this entails Japan to be proud of its historical achievements and stand up to states such as China. See Abe (2013).
} 
against Japan. A conservative Japanese commentator, Kuroda (2017: 129), argued in June 2017 that South Korean NGOs' 'patriotic populism' (aikoku popyurizumu) frequently frustrates South Korean attitudes towards Japan, insinuating that the Moon administration might be susceptible to such pressures (Kuroda, 2017: 131). Likewise, Japanese politicians reacting to official Japanese apologies are another factor. Ideas expressed in the 1990s such as Japan helped liberate Asia (Wakamiya, 2006: 258-259), that Japan was not intent on invading Asia (Wakamiya, 2006: 261), or that the annexation was agreed cordially (Wakamiya, 2006: 262) elicit South Korean anger and a counter-response from Japan.

Likewise, domestic political constraints put additional pressure on the South Korean government. Lee Myung-bak's Dokdo visit in 2012 was partly in response to domestic pressure; and the Park scandal and impeachment precipitated the unravelling of the December 2015 Agreement. The abrupt way in which the Agreement was reached (Gil, 2017) and the Park administration's elusiveness about the negotiations (Hankyoreh, 2015) did not help win the support of the South Korean public. Moreover, a series of court rulings on Comfort Women and forced labour constrained South Korean government's room for manoeuvre. Prime Minister Lee Nak-yeon stated in November 2018 'that the government many not interfere in the decisions of the judiciary is the fundamental principle of democracy' (Noh and Kim, 2018), with the leader of Bareunmirae party, Sohn Hak-kyon, adding that the 'Supreme Court ruling is something we must respect as a judgement' (Lee, 2018). Hence, domestic factors also collude to frustrate attempts at reconciliation.

To be sure, there are sympathetic voices from within Japanese elite circles. Prime Minister Kan Naoto's August 2010 address commemorating the centenary of annexation admits that it is easy for the one inflicting pain to forget, and hard for the one receiving pain to forget' (Kantei, 2010). Kōno Yōhei, who issued the 1993 remark, stated in October 2012 that he is 'saddened to hear people arguing over half a century after the war as though these suffering women and their wartime tragedy never existed, pointing to the lack of documentary evidence' (Jeong, 2012). A former prime minister, Hatoyama Yukio, told a conference in August 2015 that 'expressions of our [remorse] must continue until such time as the people in the wounded countries tell us "you can stop now", adding that ' $t$ true patriotism is the courage to not close your eyes to the historical facts of the past and to know how to apologize for your wrongs' (Kim, 2015). In October 2018, Hatoyama noted that, 'Prime Minister Abe did apologize at the time of the 2015 agreement, but he came across as overbearing to the Korean public [by his use of the phrase irreversible] and hurt [Korean] feelings' (Kim, 2018c). For Hatoyama, 'Japan needs to apologize for having inflicted great pain upon the people of China and Korea through the wrong wars it started in the past. A forward-looking relationship will form when the people who were hurt say no more apologies are necessary' (Kim, 2018c). Despite such sympathetic voices in Japan and both governments' efforts at reconciliation, various factors conspire to frustrate the process. Mounting frustrations on both sides only reinforce the resignation that difficulty is the prevailing condition.

As Maruyama (1961: 126-128) warned us, it is very difficult to dispel reified realities as they take on lives of their own. Once the realities of troublesome neighbours are established, it becomes difficult for both the Japanese and South Korean governments to disown them, since doing so would be tantamount to making concessions and potentially 'losing face'. As such, the logical conclusion to the clash of realities points in a single direction: that the relationship will deteriorate further unless either government can countenance 'losing face' in the process. Of course, exogenous factors might help prompt Japan and South Korea to improve their relationship. After all, they both share similar threat perceptions on North Korea, as well as shared concerns over Trump administration's security commitments in the region. Worsening of the regional security environment could potentially break the downward-spiral of bilateral relations, as security imperatives of both Japan and South Korea might impel both sides to put aside their differences. So, the possibility for improvement remains, but the chances are that the downward spiral of reification will continue for the foreseeable future. 


\section{Conclusion}

Both the Japanese and South Korean governments consider the onus is on the other side to improve the relationship. For Japan, South Korea is a troublesome neighbour and South Korea defines Japan to be insincere. For both Tokyo and Seoul, the reality of having to cope with a troublesome/insincere neighbour in a difficult relationship is a reification, since the difficulty has become a Maruyama-esque bakemono that took on a life of its own. The bakemono boomerangs back on to Japanese and South Korean policy elites to help endorse the difficult reality. As a reification, authors are unaware of their own authorship of the bakemono.

The difficult Japan-South Korea relationship displays the stickiness of reality: so long as Japanese and South Korean policy elites believe that the onus of improvement lies with the neighbour, the lack of self-reflection makes reconciliation difficult, reinforcing the difficult dynamic. This makes reification a useful concept in international relations theorizing. Using reification enables us to go a step further in making sense of the emergent intersubjective structure as seem from the perspectives of the participants - the co-authors in the clash of realities. Comparing and contrasting the Japanese reality of its difficult relationship with South Korea, and vice-versa, helps us to appreciate the characteristics of reified images that lie at the heart of international conflicts. This mode of thinking can be applied to any interaction between and among the various international actors. The precision of reified reality is not the issue here: what matters is that the figments of actors' imaginations have a discernible impact. The clash of realities fuels recurring conflicts, and Japan-South Korea relations provide a fine example of the downward spiral.

As a reification, it is always possible, but less probable, that the difficult and often fraught relationship between Tokyo and Seoul can be deconstructed and improved. Only when Japanese and South Korean policy elites both realize that the prevailing reality needs to be jettisoned can the two governments move towards constructing a new reality. The sense of condescension towards South Korea is widely shared and ingrained among the Japanese policy elites; and the idea that Japanese policy elites are insincere towards the historical pain and sufferings of Koreans persists within South Korean policy circles. The stickiness of reified reality is difficult to dispel. The bilateral clash of realities means that neither government is likely to question the veracity of their realities unless there is a significant change that prompts fundamental rethink of their own beliefs and help to dispose of the conviction that it is always the neighbour's fault. The logical conclusion is for this clash of realities to fuel a downward spiral of deteriorating relations into a self-fulfilling prophecy of a perpetually difficult relationship. If the Japan-South Korea relationship is to improve, stakeholders - in both Japan and South Korea - need the courage and creativity to challenge the perceived realities. This is no easy task; but unless courage is found to seek a genuine reconciliation, the bilateral relationship will forever be doomed to repeat the cycle of mutual invectives.

Acknowledgements. I would like to thank the editors and reviewers for their constructive comments and engagement throughout. I would also like to thank: Ruth Kinna for her support and encouragement; Young Chul Cho, for his very helpful tips; as well as the participants at the 2018 European International Studies Association conference in Prague for their helpful suggestions.

\section{References}

Abe S (2013) Atarashii kuni-e [Towards a New Country]. Tokyo: Bunshun shinsho.

Ahn C-H (2011) President Lee confronts Japanese prime minister over comfort women issue. Hankyoreh, December 19. Available at http://english.hani.co.kr/arti/english_edition/e_national/510857.html (Accessed 21 November 2018).

Ahn C-H (2012a) President Lee urges Japan to own up to sexual slavery. Hankyoreh, March 2. Available at http://english. hani.co.kr/arti/english_edition/e_national/521698.html (Accessed 21 November 2018).

Ahn C-H (2012b) President Lee says visit to Dokdo was long in the works. Hankyoreh, August 14. Available at http://english. hani.co.kr/arti/english_edition/e_international/547039.html (Accessed 21 November 2018).

Archer MS (1995) Realist Social Theory: The Morphogenetic Approach. Cambridge: Cambridge University Press.

Archer MS (1996) Culture and Agency: The Place of Culture in Social Theory, Rev. Edn. Cambridge: Cambridge University Press. 
Asahi shimbun (2017a) “'Kankoku, zehi otona no gaikō wo” Nukaga Nikkan-giren kaichō' ['South Korea should conduct diplomacy of a grown-up', president of parliamentary league, Nukaga]. Asahi shimbun, November 9. Available at http://www.asahi.com/articles/ASKC9571JKC9UTFK00G.html (Accessed 30 November 2017).

Asahi shimbun (2017b) 'Chōyōkō meguru hatsugen, kenen tsutaeru. Mun daitōryō ni Nukaga Nikkan giren kaichō’ ['I will convey my concern over forced labourer to President Moon', Nukaga, president of Japan-South Korea parliamentary league. Asahi shimbun, August 22. Available at http://digital.asahi.com/articles/DA3S13097044.html (Accessed 30 November 2017).

Asahi shimbun (2017c) 'Shōjozō basu, Suga kanbō-chōkan "tekisetsu na taiō wo Kankoku ni mōshi-ire”' ['Regarding the bus with the statue of a girl, proper treatment needed', Chief Cavbinet Secretary, Suga, to tell South Korea. Asahi shimbun, August 15. Available at http://digital.asahi.com/articles/ASK8H454DK8HULFA00D.html (Accessed 30 November 2017).

Asahi shimbun (2017d) 'Suga-shi “hatsugen suru ki ni naranai” Kankoku shōjozō basu ni fuakaikan' ['Suga, “I don't feel like commenting”, frustration over the statue of girl on a bus']. Asahi shimbun, August 14. Available at http://digital.asahi.com/ articles/ASK8G7QNVK8GULFA013.html (Accessed 30 November 2017).

Asahi shimbun (2017e) 'Nikkan, sōgo hōmon saikai e, ianfu, tsuitotsu wa kaihi, shunō gōi' ['Leaders agree to mutual visits, prevents clash over comfort women']. Asahi shimbun, August 5. Available at http://digital.asahi.com/articles/ DA3S13024903.html (Accessed 30 November 2017).

Asahi shimbun (2017f) 'Abe-shi "Nikkan gōi, sekinin motte jisshi", Mun-shi "kokumin dai-tasū ukeirerarezu" Nikkan shunō, hatsu no denwa-kyōgi' ['First telephone summit. Abe "to implement bilateral agreement responsibly". Moon, "majority cannot accept agreement"]. Asashi shimbun, May 12. Available at http://digital.asahi.com/articles/DA3S12933040.html (Accessed 30 November 2017).

Asahi shimbun (2017g) 'Suga chōkan "Nikkan kankei no setsujitsu na jisshi wo", Kankoku shin-daitōryō shūnin de' [Chief Cabinet Secretary Suga on new South Korean president taking office, 'Sincere implementation of agreement needed']. Asahi shimbun, May 10. Available at http://digital.asahi.com/articles/ASK5B41YKK5BUTFK004.html (Accessed 30 November 2017).

Asahi shimbun (2017h) “'Atarashii Nikkan kankei e kitai, seiji ga uragiruna”, Jimin Nukaga-shi' [LDP Nukaga, 'Looking forward to a new Japan-South Korea relationship. Politics should not betray']. Asashi shimbun, January 12. Available at http://digital.asahi.com/articles/ASK1D61W6K1DUTFK00Z.html (Accessed 30 November 2017).

Asahi shimbn (2017i) “Kankoku wa daiji daga, naka naka mendō na kuni da”, jimin Nikai-shi' [LDP Nukaga, 'South Korea is important, but a cumbersome country']. Asahi shimbun, January 6. Available at http://digital.asahi.com/articles/ ASK166WFNK16UTFK013.html (Accessed 30 November 2017).

Asahi shimbun (2017j) 'Shōjo-zō taiō shinai Kankoku "rikai dekinu”, Nukaga Nikkan-giren kaichō' [Japan-South Korea parliamentary league president, 'Cannot understand South Korea's inaction over the statue of a girl']. Asahi shimbun, January 6. Available at http://digital.asahi.com/articles/ASK1662XRK16UTFK00N.html (Accessed 30 November 2017).

Asahi shimbun (2018a) 'Nikkan, wakai no chikai michi-nakaba' [Japan-South Korea, immature reconciliation]. Asahi shimbun, November 14. Available at https://digital.asahi.com/articles/DA3S13767383.html?iref=pc_ss_date (Accessed 21 November 2018).

Asahi shimbun (2018b) “Nikkan shunō, hi-kōshiki de kaidan wo" Ban Ki-mun zen-Kokuren jimu sōchō' [Japan-South Korea leaders should hold informal talks: previous United Nations Secretary General, Ban Ki-moon]. Asahi shimbun, November 25. Available at https://digital.asahi.com/articles/ASLCR56NLLCRUHBI00R.html? rm=347(Accessed 24 November 2018).

Bae H-J (2017) Moon, Abe at odds over wartime sex slavery deal. Korea Herald, July 7. Available at http://www.koreaherald. com/view.php?ud=20170707000775 (Accessed 22 December 2018).

Banno J (2013) Kindai Nippon to Ajia [Modern Japan and Asia]. Tokyo: Chikuma gakugei bunko.

Bieler A and Morton AD (2008) The deficits of discourse in IPE: turning base metal into gold? International Studies Quarterly 52, 103-128.

Cho K-W (2019) Japan lashes out at S. Korea for 'attempting to shift responsibility' for forced labor victims. Hankyoreh, January 12. Available at http://english.hani.co.kr/arti/english_edition/e_international/878129.html (Accessed 15 March 2019).

Choi H-J (2015) President Park pressuring Abe toward quicker 'decision' on comfort women issue. Hankyoreh, November 14. Available at http://english.hani.co.kr/arti/english_edition/e_international/717440.html (Accessed 21 November 2018).

Choi H-J, Park S-J and Gil Y-H (2015) S. Korea and Japan allude to possible progress on comfort women issue. Hankyoreh, November 3. Available at http://english.hani.co.kr/arti/english_edition/e_international/715732.html (Accessed 21 November 2018).

Duus P (1995) The Abacus and the Sword: The Japanese Penetration of Korea, 1895-1910. Berkeley: University of California Press.

Elder-Vass D (2007) For emergence: refining archer's account of social structure. Journal for the Theory of Social Behaviour 37, 25-44.

Elder-Vass D (2010) The Causal Power of Social Structures: Emergence, Structure and Agency. Cambridge: Cambridge University Press. 
Elder-Vass D (2012) The Reality of Social Constructs. Cambridge: Cambridge University Press.

Gaikō (2010) 'Nippon gaikō no shin-chōryū to chokumen suru kadai' [The new wave in Japanese foreign policy and its challenges]. Gaikō, September, 10-20.

Gil Y-H (2014) Former Japanese Prime Minister asks Pres. Park to stop using 'tattletale diplomacy'. Hankyoreh, January 11. Available at http://english.hani.co.kr/arti/english_edition/e_international/619321.html (Accessed 21 November 2018).

Gil Y-H (2017) Comfort women agreement: a diplomatic debacle in three acts. Hankyoreh, January 10. Available at http:// english.hani.co.kr/arti/english_edition/e_international/778148.html (Accessed 14 March 2019).

Gil Y-H and Kim K-W (2014) Foreign ministry says Japan's recent comments undermine historical understanding. Hankyoreh, February 22. Available at http://english.hani.co.kr/arti/english_edition/e_international/625370.html (Accessed 21 November 2018).

Gil Y-H, Son W-J and Seok J-H (2015) Park and Abe participate in commemorative ceremony, following foreign ministers meeting. Hanknyoreh, June 22. Available at http://english.hani.co.kr/arti/english_edition/e_international/696951.html (Accessed 21 November 2018).

Hankyoreh (2015) On comfort women issue, principle must come before politics. Hankyoreh, June 15. Available at http:// english.hani.co.kr/arti/english_edition/e_editorial/696001.html (Accessed 14 March 2019).

Honneth A (2005) Reification: a recognition-theoretical view. The Tanner Lecture on Human Values, University of California, Berkeley, 14-16 March. Available at www.tannerlectures.utah.edu/lectures/documents/Honneth_2006.pdf (Accessed 31 January 2012).

Huffington Post (2014) 'Abe shushō, Kōno danwa minaoshi wa “kangaete inai” kenshō sagyō wa keizoku' [Prime minister Abe, I am not considering revising Kōno remark. Assessment will continue]. The Huffington Post, March 14. Available at https://www.huffingtonpost.jp/2014/03/14/abe-comfort-women_n_4961680.html (Accessed 2 January 2019).

Iriye A (1966) Nippon no gaikō [Japan's Diplomacy]. Tokyo: Chūkō shinsho.

J-Cast News (2014) Noda zen-shushō, 'Noda Seiken demo Nikkan kankei warukatta' [Previous prime minister, Noda: relations bad even under Noda administration]. J-Cast News, August 19. Available at https://www.j-cast.com/2014/08/ 19213421.html (Accessed 30 December 2018).

Jeong N-K (2012) Prominent Japanese says don't deny guilt with comfort women. Korea Herald, October 10. Available at http://english.hani.co.kr/arti/english_edition/e_international/555131.html (Accessed 21 November 2018).

Jung I-H (2017a) PM and acting president advises not to 'aggravate' comfort women situation with Japan. Hankyoreh, January 11. Available at http://english.hani.co.kr/arti/english_edition/e_national/778284.html (Accessed 21 November 2018).

Jung I-H (2017b) In conversation with Japanese PM, Pres. Moon says majority of S. Koreans don't accept comfort women agreement. Hankyoreh, May 12. Available at http://english.hani.co.kr/arti/english_edition/e_international/794487.html (Accessed 21 November 2018).

Jung Y-G and Jung I-H (2017) Pres. Moon says South Koreans 'frankly cannot accept' comfort women agreement. Hankyoreh, June 13. Available at http://english.hani.co.kr/arti/english_edition/e_national/798631.html (Accessed 21 November 2018).

Kagotani K, Kimura K and Weber JR (2014) Democracy and diversionary incentives in Japan-South Korea disputes. International Relations of the Asia-Pacific 14, 33-58.

Kantei (2010) 'Naikaku sōri-daijin danwa (Kan Naoto)' [Prime minister remark (Kan Naoto)]. August 10. Available at https://www.kantei.go.jp/jp/kan/statement/201008/10danwa.html (Accessed 2 December 2018).

Kantei (2012) 'Ri Myonbaku Kankoku daitōryō no Takeshima jōriku eno taiō shochi ni tsuite' [On the response to South Korean president Lee Myung-bak's visit to Takeshima]. August 17. Available at http://www.kantei.go.jp/jp/tyoukanpress/ 201208/17_a.html (Accessed 14 April 2017).

Kantei (2013) 'Nikkan, Kannichi kyōryoku iinkai gōdō sōkai kaikai-shiki' [Opening ceremony of the Japan-South Korea, South Korea-Japan co-operation council meeting]. November 15. Available at http://www.kantei.go.jp/jp/96_abe/ actions/201311/15soukai.html (Accessed 24 February 2017).

Kantei (2014) 'Kōno danwa sakusei ni kansuru kenshō sagyō ni tsuite' [On the report into Kōno remark]. June 20. Available at https://www.kantei.go.jp/jp/tyoukanpress/201406/20_p.html (Accessed 2 January 2019).

Kantei (2015a) 'Nikkan shunō kaigi' [Japan-South Korea summit]. November 2. Available at http://www.kantei.go.jp/jp/ 97_abe/actions/201511/02kaidan.html (Accessed 24 February 2017).

Kantei (2015b) 'Nikkan kokkō seijō-ka 50-nen kinen-shiki' [Japan-South Korea normalization $50^{\text {th }}$ anniversary ceremony]. June 22. Available at http://www.kantei.go.jp/jp/97_abe/actions/201506/22kan_nichi50.html (Accessed 24 February 2017).

KH Digital 2 (2015) Japan officially apologizes, offers funds. Korea Herald, December 28. Available at http://www.koreaherald.com/view.php?ud=20151228000889\&ACE_SEARCH=1 (Accessed 28 November 2018).

KH Digital 2 (2016) Parties slam Japan on sex slavery stance. Korea Herald, February 1. Available at http://www.koreaherald. com/view.php?ud=20160201001092\&ACE_SEARCH=1 (Accessed 28 November 2018).

Kim Y-S (1995) Nikkan kankei no sai-kōhicku to Ajia [Reconstruction of Japan-South Korea Relations and Asia]. Fukuoka: Kyūshū daigaku shuppankai.

Kim O-H (2015) Former Japanese PM says Tokyo should continue with apologies until victims say 'enough'. Hankyoreh, August 14. Available at http://english.hani.co.kr/arti/english_edition/e_international/704477.html (Accessed 21 November 2018). 
Kim J-E (2017) President calls for two-track approach in South Korea-Japan relations. Hankyoreh, August 16. Available at http://english.hani.co.kr/arti/english_edition/e_international/807056.html (Accessed 21 November 2018).

Kim J-E (2018a) SK Foreign Minister says 'anything is possible' regarding 2015 comfort women agreement with Japan. Hankyoreh, January 5. Available at http://english.hani.co.kr/arti/english_edition/e_national/826503.html (Accessed 21 November 2018).

Kim J-E (2018b) Moon administration will not renegotiate 2015 comfort women agreement. Hankyoreh, January 10. Available at http://english.hani.co.kr/arti/english_edition/e_international/827149.html (Accessed 21 November 2018).

Kim K-S (2018c) Former Japanese prime minister reflects on issue of sex slaves at Pusan National University. Hankyoreh, October 3. Available at http://english.hani.co.kr/arti/english_edition/e_international/864282.html (Accessed 21 November 2018).

Kim J-E and Cho K-W (2018) Moon and Abe hold summit prior to Pyeongchang Olympics opening ceremony. Hankyoreh, February 20. Available at http://english.hani.co.kr/arti/english_edition/e_international/831720.html (Accessed 21 November 2018).

Kim B-H and Hwang Y-R (2018) Moon hints to Abe that Reconciliation and Healing Foundation needs to be disbanded. Hankyoreh, September 27. Available at http://english.hani.co.kr/arti/english_edition/e_international/863576.html (Accessed 21 November 2018).

Kinohara T and Makino Y (2019) 'Akka tomaranu Nikkan kankei “Takeshima no hi” ni hihan no ōshü' [Degenerating Japan-South Korea relations. Exchange of criticisms on 'Takeshima day']. Asahi shimbun, February 23. Available at https://digital.asahi.com/articles/ASM2Q54KHM2QUTFK014.html (Accessed 15 March 2019).

Kiyomiya R and Takeda H (2018) 'Kōno gaishō “kankei no kiban, konpon kara sokonawareta” Kankoku gaishō ni' [Foreign minister Kōno tells South Korean foreign minister, 'the basis for relationship fundamentally damaged']. Asahi shimbun, October 31. Available at https://digital.asahi.com/articles/ASLB0334QLB0UTFK008.html (Accessed 15 March 2019).

Kiyomiya R (2018) 'Chōyōkō hanketsu wa "bōkyo, kokusai chitsujo eno chōsen” Kōno gaishō hihan' [Forced labourers ruling is 'reckless and challenge to international order'. Foreign minister Kōno condemns]. Asahi shimbun, November 6. Available at https:/digital.asahi.com/articles/ASLC65JB8LC6UTFK015.html?iref=pc_ss_date (Accessed 21 November 2018).

Kuroda K (2017) 'Sayoku daitōryō-tanjō ni otaota suruna' [Don’t be scared of left-wing president]. Bungei shunjū, June: 122-31.

Lee S (2013) Burying the hatchet? The sources and limits of Japan-South Korea security cooperation. Asian Security $\mathbf{9}$, 93-110.

Lee J (2016a) 'Dokuto mondai ni taisuru Kankoku-jin no ninshiki: ryōyūken to rekishi, ishū-rinkēji no katei to kōzō' [South Korean perceptions on Dokto problem: territoriality and history, process and structure of issue linkage]. PRIME 39, 3-14.

Lee SH $(2016 b)$ North Korea in South Korea-Japan relations as a source of mutual security anxiety among democratic societies. International Relations of the Asia-Pacific 16, 273-301.

Lee K-M (2018) Japanese diet delegation debates with Korean conservative parties on ruling on forced labor. Hankyoreh, November 6. Available at http://english.hani.co.kr/arti/english_edition/e_international/869080.html (Accessed 15 March 2019).

Lee J-H and Gil Y-H (2016) Following public outcry, government returns to strict stance on comfort woman statue. Hankyoreh, January 6. Available at http://english.hani.co.kr/arti/english_edition/e_international/724977.html (Accessed 21 November 2018).

Lee J-H and Kim Y-D (2017) S. Korean Foreign Minister to seek 'feasible solution' on Busan comfort woman statue. Hankyoreh, January 14. Available at http://english.hani.co.kr/arti/english_edition/e_international/778711.html (Accessed 21 November 2018).

Lind J (2010) Sorry States: Apologies in International Politics. Cornell University Press.

Makino Y (2018) “Kankoku seifu ga moto chōyōkō e no baishō-kin katagawari wo" Kon No-myon moto Kankoku gaishō ni kiku' [South Korea should pay forced labourers, former foreign minister Gong Ro-myung]. Asahi shimbun, November 15. Available at https://digital.asahi.com/articles/DA3S13769136.html?iref=pc_ss_date (Accessed 29 November 2018).

Makino Y (2019) 'Kankoku daitōryō ga Nihon hihan "Seijika ga sōten-ka, kenmei dewa nai”' [South Korean president criticizes Japan. 'Politicians turned it into an issue, unwise']. Asahi shimbun, January 10. Available at https://digital.asahi.com/ articles/ASM1B3VWGM1BUHBI013.html?iref=pc_ss_date (Accessed 15 March 2019).

Maruyama M (1961) Nihon no shisō [Japanese Thought]. Tokyo: Iwanami shinsho.

Mizuno H and Osaki T (2018) Abe explains uncompromising stance on inserting 'explicit SDF mention' in Article 9. The Japan Times, February 5. Available at https:/www.japantimes.co.jp/news/2018/02/05/national/politics-diplomacy/abeexplains-uncompromising-stance-inserting-explicit-sdf-mention-article-9/\#.WnwUUqhl-Um (Accessed 8 February 2018).

MOFA (2015) 'Kishida gaimu daijin kaiken kiroku' [Record of Foreign Minister Kishida's briefing]. February 20. Available at http://www.mofa.go.jp/mofaj/press/kaiken/kaiken4_000186.html (Accessed 30 November 2017).

MOFA (2017a) Parliamentary Vice-Minister for Foreign Affairs Kiyoshi Odawara's Article contributed to Wall Street Journal, January 30, 2017. February 3. Available at http://www.mofa.go.jp/p_pd/ip/page4e_000579.html (Accessed 24 February 2017).

MOFA (2017b) 'Pusan no ian-fu zō setchi ni kansuru Kawamura zen-gaimu hōdōkan no Japan taimuzu-shi e no kikō' [Former MOFA spokesperson, Kawamura's, article in the Japan Times]. January 25. Available at http://www.mofa.go. jp/mofaj/page4_002718.html (Accessed 24 February 2017). 
Mutō M (2017) 'Ianfu-mondai wo mushikae saseruna' [Do not revive he comfort women issue]. Bungei shunjū, January, 286-90.

Mutō M (2018) 'Kankoku “chōyō-kō hanketsu”: Mun je-in wa issen wo koeta' [South Korean 'forced labour ruling: Moon Jae-in has crossed a line']. Bungei shunjū, December, pp. 174-181.

Nihon keizai shimbun (2016a) 'Yoyatō, Nikkan kankei kōtai wo keikai' [The ruling and opposition parties wary of set back in Japan-South Korea relations]. Nihon keizai shimbun, November 30, p. 4.

Nihon keizai shimbun (2016b) “"Mirai-shikō" Nikkan ni nao kabe' [Barriers to future-oriented Japan-South Korea relations]. Nihon keizai shimbun, September 8, p. 4.

Nihon keizai shimbun (2017a) 'Shushō "1 miri mo ugokazu”: Nippon-gawa, minaoshi ōjinu kamae' [Prime Minister, 'will not move a millimeter'. Japan not to give in to revision]. Nihon keizai shimbun, December 28, p. 3.

Nihon keizai shimbun (2017b) 'Nihon seifu wa genjū ni kōgi' [Japanese government to protest]. Nihon keizai shimbun, November 8, p. 9.

Nihon keizai shimbun (2017c) 'Chūkan taishi ni ichiji-kikoku shiji' [Ambassador to South Korea to return]. Nihon keizai shimbun (Evening edition), January 6, p. 1.

Nihon keizai shimbun (2018) 'Shushō kondan no yōshi' [Summary of Prime Minister's conversation]. Nihon keizai shimbubn, January 16, p. 4.

Nikai T (with Shinohara Fumiya) (2017) 'Jimin kanjichō subete no gimon ni kotaeru' [Secretary General of LDP to answer all questions]. Bungei shunjū, July, 124-32.

Nishioka T (2016) Kakon nokoshita 'ianfu' Nikkan gōi. Kokusai shakai ni ryūfu sareta kyogi ni 'danko taru hanron' ga dekinaku nari wa shinaika? Sankei shimbun, January 6. Available at https://www.sankei.com/politics/news/160106/ plt1601060009-n1.html (Accessed 7 January 2019).

Noh J-W and Kim B-H (2018) S. Korean prime minister addresses Japan's attitude on forced labor ruling. Hankyoreh, November 8. Available at http://english.hani.co.kr/arti/english_edition/e_international/869438.html (Accessed 15 March 2019).

Onchi Y (2019) 'Kankoku kyōkō shisei no aku-junkan' [The downward spiral of South Korea's firm stance]. Nihon keizai shimbun, February 14, p. 4.

Park B-S (2013) In memorial address, President Park calls on Japan to correct its interpretation of history. Hankyoreh, March 2. Available at http://english.hani.co.kr/arti/english_edition/e_international/576257.html (Accessed 21 November 2018).

Park H-N (2015) S. Koreans 'disappointed' with rhetoric, absence of new apology in Abe statement. Korea Herald, August 14. Available at http://www.koreaherald.com/view.php?ud=20150814000172\&ACE_SEARCH=1 (Accessed 28 November 2018).

Pitkin HF (1987) Rethinking reification. Theory and Society 16, 263-293.

Rozman G and Lee S-W (2006) Unravelling the Japan-South Korea 'virtual alliance'. Asian Survey 46, 761-784.

Sakaki A and Nishino J (2018) Japan's South Korea predicament. International Affairs 94, 1-20. Online First. doi: 1093/ia/ iiy029 (Accessed 22 June 2018).

Sankei shimbun (2012) 'Nippon ga yoron akka saseta' jōhō kyōtei enki de Kankoku. Sankei shimbun, July 16. Available at https://web.archive.org/web/20120717050247/; http://sankei.jp.msn.com/world/news/120716/kor12071623230006-n1.htm (Accessed 18 December 2018).

Sankei shimbun (2016) 'Hoshu dantai ga "jūdai kashitsu” to hihan. Tonai de shūkai' [Conservative groups condemn as 'serious breach']. Sankei shimbun, February 7. Available at https://www.sankei.com/affairs/news/160207/afr1602070029-n1. html (Accessed 7 January 2019).

Seok J-H (2014) Pres. Park welcomes Abe's claim, but urges concrete action. Hankyoreh, May 17. Available at http://english. hani.co.kr/arti/english_edition/e_international/628545.html (Accessed 21 November 2018).

Seoung Y-C (2018a) Moon says S. Korea and Japan can 'become true friends' if historical differences are settled. Hankyoreh, November 20. Available at http://english.hani.co.kr/arti/english_edition/e_international/871037.html (Accessed 21 November 2018).

Seoung Y-C (2018b) 'Moon says S. Korea and Japan can "become true friends" if historical differences are settled'. Hankyoreh, November 20. Available at http://english.hani.co.kr/arti/english_edition/e_international/871037.html (Accessed 15 March 2019).

Silva S (2013) Reification and fetishism: process of transformation. Theory, Culture \& Society 30, 79-98.

Suzuki S (2019) 'Kankoku gichō, shazai yōkyū kobamu' [South Korean speaker of assembly refuse apology]. Nihon keizai shimbun, February 18, p. 3.

Takita M and Abiru R (2018) 'Abe Shinzō shushō, PyeongChang gorin shusseki e, tandoku-intabyū de hyōmei "Nikkan-gōi shin-hōshin wa ukeirerarenu. Mun daitōryō ni chokusetsu tsutaetai"' [Prime Minister Abe to attend PeyongChang Olympics. To tell President Moon that Japan will not accept revisiting the bilateral agreement]. Sankei shimbun, January 24. Available at http://www.sankei.com/politics/amp/180124/plt1801240003-a.html?_twitter_impression=true (Accessed 24 January 2018).

Tamaki T (2010) Deconstructing Japan's Image of South Korea: Identity in Foreign Policy. London: Palgrave. 
Wakamiya Y (2006) Wakai to nashonarizumu. Tokyo: Asahi shimbunsha.

Wiegand KE (2015) The South Korean-Japanese security relationship and the Dokdo/Takeshima islets dispute. The Pacific Review 28, 347-366.

Yamada K (2016) 'Sōryōjikan mae ni shōjo-zō' [Statue of girl in front of the consulate]. Nihon keizai shimbun, December 31 , p. 2. Yamagishi K (2017) 'Hōkanchū no Nikai-shi "warudakumi suru renchū, mitusketara bokumetu shite"' [Nikai on visit to South Korea: get rid of sinister forces]. Asahi shimbun, June 10. Available at http://digital.asahi.com/articles/ ASK6B62PZK6BUTFK00B.html (Accessed 30 November 2017).

Yonhap (2018) Moon says Japan has no right to claim sex slave issue settled. Korea Herald, March 1. Available at http://www. koreaherald.com/view.php?ud=20180301000060\&ACE_SEARCH=1 (Accessed 28 November 2018).

Cite this article: Tamaki T (2020). It takes two to Tango: the difficult Japan-South Korea relations as clash of realities. Japanese Journal of Political Science 21, 1-18. https://doi.org/10.1017/S1468109919000161 